\title{
Classification of Zayandehrud River Basin Water Quality Regarding Agriculture, Drinking, and Industrial Usage
}

\section{Mohammad Salarian ${ }^{1}$, Masumeh Najafi' ${ }^{2}$, V Vahid Hosseini ${ }^{3}$, Mohammad Heydari ${ }^{4}$}

${ }^{1} \mathrm{PhD}$ Student ofIrrigation and Drainage, Department of Agriculture, Ferdowsi University of Mashhad

${ }^{2}$ Graduated Student of Irrigation and Drainage, Department Of Agriculture, Isfahan University of Technology

${ }^{3}$ Graduated Student at RS \& GIS, Department of Geography, Kharazmi University, Tehran

${ }^{4} \mathrm{PhD}$ Student of Water Resources, Department of Civil Engineering, University of Malaysia, Kuala Lumpur,

Malaysia

m3heydariii@yahoo.com

Abstract: Iran is located in arid and semi-arid of the world and it has shortage of freshwater resources. So, to review the status of water use and protection of water resources against pollution, especially in the global water crisis is necessary and vital. Zayandehrud River as the largest river of the central plateau of Iran and the most important surface water flow in Isfahan province, which preserving its quality is important because of agriculture - environmental, industry and drinking. In this regard, the assessment of the quality of the 15 stations in the Zayandehrud river basin has been done by using the analysis of physical and chemical parameters to during 5 decades from 1967-2009. Surveying the results shows thatdrinking water quality based on the diagram Schuler is good and acceptable. Regarding agriculture and irrigation, according to Wilcox diagram, except for two stations Hossein Abad and Henjin which were salty)C3S1), the other stations suitable were a bit salty but suitable for agriculture (C2S1). Water quality of ten stations has been hard water; four stations fairly hard and the only Henjin station has been estimated quite hard. The type and faces of this basin water have beenchock bicarbonate at 13 stations and in two stations Hossein Abad and Henjin have been sodic sulfate and Magnesium Sulfated. Qualitative classification of stations based on both industrial and according to Langelier index is estimated to be corrosive except Hossein Abad station that has been deposited.

Keywords: Crisis - Water Quality - Zayandehrud - Wilcox - Schuler - Langelier

\section{INTRODUCTION}

The surface water or rivers are the most important water resources which have a major role in supplying water required for various activities such as agriculture, industry, drinking water and electricity production. Many of the country's water resources planning are based on the potential of surface water sources. One of the problems facing for transferring river water is the amount of pollutants that exist in river water in the form of solution or suspended solids (Najafi, Tabatabai, \& Savage, 2006). Knowing the quality of water resources is one of the important requirements for the planning, development, protection and control of them (Jabari \& Najmi, 2010). Given that millions of people are affected by water pollution annually and it is considered a threat to modern societies, studying addressing surface water sources such as rivers, is one of the necessities (Mossadegh, 2003). Since information about rivers regarding capacity of pollutants entrance will help a lot in controlling pollution and future planning, many studies have been done in this field in various formats. As an example, Statistical tests of Principal Components Analysis (PCA) and Cluster Analysis )CA( are used to determine the source of contamination in the water supply and by the evaluation of multiple parameters measured in a specific time period (Chapman, Organization, \& Press, 1996), showed that pollution elements (e.g., K) must be attributed to the natural origin of geology or human origin (Pesce \& Wunderlin, 2000).ForexampleVega, Pardo, Barrado, and Debán (1998), physical and chemical variables of water have been studied by using statistical analysis during 2.5 year at the three stations regarding the assessment of seasonal changes and pollutant effects on water quality www.arjonline.org 
of pisuerga River, a Spain. In this study, the application of PAC has been showed that the amount of mineral material, human pollution and the temperature have been decreased. Toinvestigate the spatial and temporal variations of river Sequoia River, Argentina, Alberto and colleagues (2000) by using statistical methods CA and PCA, showed that the CA method showed good results but with little detail of spatial and temporal variations in water quality. It must be also mentioned that PCA method requires 13 parameters to show $71 \%$ spatial and temporal variations.

Another area of research that is used to infer the quality of river water can be cited direct study of plants and animals that live in it because aquatic organisms and communities can present the current situation, also changes over time and the effect of contaminant cumulative and biological indicators can also show hidden environmental impacts (Esmaili sari, 2003). For example, Azrina, Yap, Rahim Ismail, Ismail, and Tan (2006) studied the effects of human activities on the distribution and diversity of macro-benthic communities and water quality in Langat River, Malaysia that the relationship between physical, chemical conditions and benthic invertebrates in large communities were investigated through multiple stage regression analysis and the results showed the food and diversity of benthic invertebrates in large communities were mainly influenced by TSS and EC of river water. It is also necessary physical and chemical parameters are accurately simulated in the planning and estimated the possibility of neural network applications in the areas. For instance, Misaghi and Mohammadi (2004)by using the neural network showed that the neural network has good ability to simulate changes in the quality parameters in Zayandehrud basin and for qualitative data of BOD and DO.

In addition to the above methods, it is possible to investigate chemical quality parameters of river water by using the existing software as Hydrochemistry (AquaChem, Chemistry) and output match with Piper diagrams, Shulander and so on. Since as we know the rate of water chemical parameters depends on factors such as geological formations in the basin area, ion exchange between surface water and groundwater and the river discharge regime which in this context, for example, we can mention a few samples. Sundaray, Nayak, and Bhatta (2009)in a case study conducted in India on Mahanad river investigated the river water quality to suit for agriculture for six different time periods at 31 stations and calculated water suitability for use in agriculture by using mathematical relationships and the parameters the ratio of sodium absorbance, residual sodium carbonate, water permeability in soil and the amount of magnesium which obtained results were consistent with Wilcox diagram. Based on Wilcox index, all samples from different areas of the study classified as excellent to good (low to medium salinity with low sodium) which were appropriate for all soils and also for salt-sensitive products.Mostakmeli and Tarshiziyan (2000) recognized chemical type and kind of water in Magnesium Sulfated by Piper and Stiff diagrams through studying river water quality in Shirin-Dareh Basin in North Khorasan province. Ghasemi, Zare, Shahsavar, and Yaghobi Kikileh (2010) investigate aquifer status to examine the qualitative and quantitative changes of Hamadan - Bahar plain groundwater. They determined a few changes through water level reading in each well in different months and Polygon them in a 15 year period (1992 to 2006) and concluded that groundwater level is dropped $11 \mathrm{~m}$. They also categorized wells in two groups of quality in order to evaluate the qualitative changes by using Wilcox diagram. Results showed that due to aquifer proximity to residential and industrial areas, water quality das decreased from South-East to NorthEast of the basin.

Considering the importance of water quality monitoring, checking water quality parameters from 15 stations of Zayandehrud catchment in order to drinking, agriculture and industry will be one of the goals of the present study.

\section{Materials And Methods}

Zayandehrud catchment with $41500 \mathrm{~km}^{2}$ area, is located in the center of Iran and there is no outlet to the sea. Zayandehrud River is the largest river in this basin, which stretches from West to East and originated from Zagros Mountains and eventually goes Gavkhuni Marsh (Figure 1). The basin has semi-arid or dry climates. 
Classification of Zayandehrud River Basin Water Quality Regarding Agriculture, Drinking, and Industrial Usage

Annual rainfall is $130 \mathrm{~mm}$ on average in Isfahan city, which most of the precipitation falls in the winter; so rainfall is not significant during the summer heat season. On the other hand, temperature is high in summer and in July is about 30 degrees centigrade. Most of the precipitation falls in the cold season and temperatures is around $3{ }^{\circ} \mathrm{C}$. Annual potential evaporation is $1500 \mathrm{~mm}$. All these figures and numbers confirm the fact that an economic farming is impossible without controlled irrigation and good management. The First and the main Supplier source of water requirement for Dashte-Isfahan is Zayandehrud River and other sources such as streams, canals and wells don't have important role in providing needed water. Geographic characteristics and statistical periods (during 5 decades 1967-2009) for some stations under study in Zayandehrud basin are presented in Table 1.
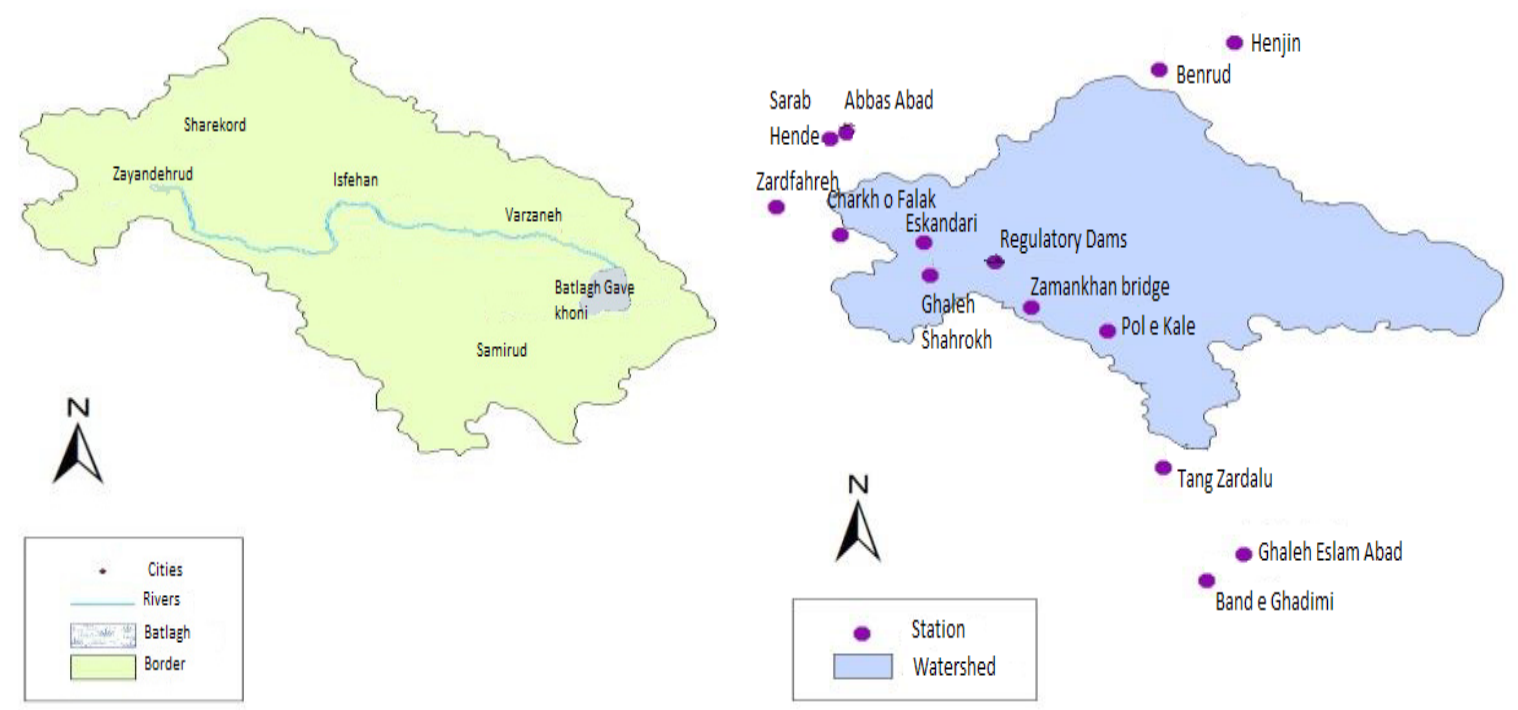

Fig1. Zayandehrud River Catchment and Stations under Study

Table1. Geographic Characteristics and Statistical Period for some Stations under Study in Zayandehrud basin

\begin{tabular}{|l|l|l|l|l|l|l|}
\hline Station & River & Sign & UTM (x) & UTM (y) & \multicolumn{2}{|l|}{ Statistical period } \\
\hline Ghaleh Eslam Abad & Bahmanzaad & A & 576938 & 3451837 & 1997 & 2009 \\
\hline Zardfahreh & Vahargan & B & 388441 & 3653311 & 1982 & 2009 \\
\hline Tang Zardalu & Kasgan & C & 543576 & 3502139 & 1977 & 2009 \\
\hline Charkh o Falak & Sibak & D & 413016 & 3639270 & 1982 & 2009 \\
\hline Band e Ghadimi & Tang Sahari & E & 561690 & 3435721 & 1995 & 2009 \\
\hline Benrud & Benrud & F & 541441 & 3734051 & 1967 & 2009 \\
\hline Hossein Abad & Ghohrud & G & 546242 & 3738137 & 1967 & 2010 \\
\hline Sarab Hende & Darband & H & 410029 & 3694174 & 1967 & 2011 \\
\hline Abbas Abad exit & Golpayegan Dam & I & 416311 & 3697475 & 1970 & 2009 \\
\hline Ghaleh Shahrokh & Zayandehrud & J & 448713 & 3614036 & 1969 & 2009 \\
\hline Eskandari & Plasjan & K & 446977 & 3632180 & 1969 & 2010 \\
\hline Regulatory Dams & Zayandehrud & L & 475870 & 3621848 & 1967 & 2009 \\
\hline Zamankhan bridge & Zayandehrud & M & 490156 & 3595698 & 1967 & 2010 \\
\hline Pol e Kale & Zayandehrud & N & 521689 & 3581811 & 1968 & 2011 \\
\hline Henjin & Zayandehrud & O & 570769 & 3748776 & 1967 & 2012 \\
\hline
\end{tabular}


Before the analysis of water quality data, the degree of accuracy and the accuracy of chemical data is determined by calculating ionic charge balance error (error response: RE) by using the following equation:

$\mathrm{RE}=\frac{\sum \text { Cations }-\sum \text { Anions }}{\sum(\text { Anions }+ \text { Cations })} \times 100(1)$

If this value is greater than 5\%, Data reliability will be questionable. Schuler, Wilcox Graphical indicators and also Langelier index have been used for quality classification of basin water. The following is a brief description of them.

\section{Schuler Chart}

Schuler semi-log chart is used to show the primary ions $\mathrm{m}$ Eq per liter and total dry residue and total hardness of water resources in a chart. Schuler chart is commonly used for the classification of "drinking" in water hydrology reports. Drinking water are classified into six groups of good, acceptable, fair, inappropriate, totally inappropriate and potable based on five chemical parameters of sodium, chloride, sulfate, dried residues (TDS) and hardness of drinking water of (Table 2).

Table2. Classification criteria for the drinking water according to Schuler classification (Mgr/L)

\begin{tabular}{|l|l|l|l|l|l|}
\hline Quality & TH & TDS & SO4 & Cl & Na \\
\hline Good & $<250$ & $<500$ & $<145$ & $<175$ & $<115$ \\
\hline Acceptable & $250-500$ & $500-100$ & $145-280$ & $175-350$ & $115-230$ \\
\hline Average & $500-1000$ & $1000-2000$ & $280-580$ & $350-700$ & $230-460$ \\
\hline Inappropriate & $1000-2000$ & $2000-4000$ & $580-1150$ & $700-1400$ & $460-920$ \\
\hline Quite undesirable & $2000-4000$ & $4000-8000$ & $1150-2240$ & $1400-2800$ & $920-1840$ \\
\hline Non-potable & $>4000$ & $>8000$ & $>2240$ & $>2800$ & $>1840$ \\
\hline
\end{tabular}

Wilcox Diagram

One of the most important indicators for the interpretation the quality of raw water in "agriculture" is Wilcox index. Wilcox classification has been proposed by Wilcox in 1948 and has been completed three years later by Torn. The index is a very common method nowadays for classification of waters in agriculture. In this classification, two factors are considered: electrical conductivity (EC) and sodium adsorption ratio (SAR) which any of them are converted into four sections (Table 3) sections (Table 3) that the overall result is the emergence of the 16 groups (Table 4). Eventually, the quality of water is stated for various uses including irrigation.

Table3. Classification criteria for farming water according to Wilcox classification

\begin{tabular}{|l|l|l|l|l|}
\hline Water Quality & EC & Class & SAR & Category \\
\hline Excellent & $<250$ & C1 & $<10$ & S1 \\
\hline Good & $250-750$ & C2 & $10-18$ & S2 \\
\hline Average & $750-2250$ & C3 & $18-26$ & S3 \\
\hline Inappropriate & $<2250$ & C4 & $>26$ & S4 \\
\hline
\end{tabular}

Table4. Different water classification and types of quality based on Wilcox classification

\begin{tabular}{|l|l|l|}
\hline Water category & Water quality & Agriculture \\
\hline $\mathrm{C} 1 \mathrm{~S} 1$ & Freshwater & Completely harmless \\
\hline $\mathrm{C} 1 \mathrm{~S} 2, \mathrm{C} 2 \mathrm{~S} 2, \mathrm{C} 2 \mathrm{~S} 1$ & A little salty & Almost Appropriate \\
\hline $\mathrm{C} 1 \mathrm{~S} 3, \mathrm{C} 2 \mathrm{~S} 3, \mathrm{C} 3 \mathrm{~S} 1, \mathrm{C} 3 \mathrm{~S} 2, \mathrm{C} 3 \mathrm{~S} 3$ & Passion & Applying the necessary measures \\
\hline $\mathrm{C} 1 \mathrm{~S} 4, \mathrm{C} 2 \mathrm{~S} 4, \mathrm{C} 3 \mathrm{~S} 4, \mathrm{C} 4 \mathrm{~S} 4, \mathrm{C} 4 \mathrm{~S} 3, \mathrm{C} 4 \mathrm{~S} 2, \mathrm{C} 4 \mathrm{~S} 1$ & Very salty & Harmful to agriculture \\
\hline
\end{tabular}


Classification of Zayandehrud River Basin Water Quality Regarding Agriculture, Drinking, and Industrial Usage Langelier Index

One of the methods used for the prediction of corrosion characteristics or deposition of water is provided by Langelier (Takubangloo, 2003). He helped from developed theories governing water solutions in order to analyze water profile. Langelier suggested that difference between $\mathrm{pH}$ and $\mathrm{pHs}$ which are the acidity of the water (measured) and calculated acidity based on the results of the chemical analysis of water with assuming saturation of calcite or calcium carbonate can also be used as a numerical indicator of water specifications, respectively (Table 5).

Table5. Interpretation of Langelierindex amount

\begin{tabular}{|l|l|}
\hline Interpretation & Index amount \\
\hline Tend to dissolve CaCo3 (corrosive) & $\mathrm{LI}<0$ \\
\hline No corrosion and deposition & $\mathrm{LI}=0$ \\
\hline Tend to sequestration CaCo3 (sedimentation) & $\mathrm{LI}>0$ \\
\hline
\end{tabular}

\section{RESULTS AND DisCUSSION}

In order to control the quality of the data, the values of ionic charge balance error (percent error response) have been calculated according to equation 1 and is presented in Table 6 . As we have seen the data has significant quality (since the percentage error is less than $5 \%$ ).

Table6. Values of response error (RE) for the qualitative data from stations in the Zayandehrud river basin

\begin{tabular}{|l|l|l|l|}
\hline Station & Total anions & Total Cations & The percentage error \\
\hline Ghaleh Eslam Abad & 4.33 & 4.26 & 0.82 \\
\hline Zardfahreh & 3.3 & 3.27 & 0.42 \\
\hline Tang Zardalu & 4.63 & 4.62 & 0.03 \\
\hline Charkh o Falak & 3.9 & 3.89 & 0.19 \\
\hline Band e Ghadimi & 3.84 & 3.81 & 0.34 \\
\hline Benrud & 4.33 & 4.33 & 0.03 \\
\hline Hossein Abad & 10.5 & 10.3 & 1.09 \\
\hline Sarab Hende & 5.28 & 5.22 & 0.63 \\
\hline Abbas Abad exit & 5.17 & 5.08 & 0.88 \\
\hline Ghaleh Shahrokh & 3.63 & 3.62 & 0.11 \\
\hline Eskandari & 5.16 & 5.14 & 0.17 \\
\hline Regulatory Dams & 3.4 & 3.41 & 0.02 \\
\hline Zamankhan bridge & 3.49 & 3.47 & 0.26 \\
\hline Pol e Kale & 4.04 & 4.03 & 0.06 \\
\hline Henjin & 12.2 & 12.2 & 0.11 \\
\hline
\end{tabular}

The results obtained from studying hydro chemical quality of surface waters of 15 stations in the Zayandehrud river catchment by using Schuler classification are given inTable 7. According to this table, drinking water quality is good and acceptable in this basin. Figure 2 is a representative of Schuler diagram.

Table7. Percentage of each class in Schuler classification for drinking in the whole area under study

\begin{tabular}{|l|l|l|l|l|l|l|}
\hline The water classification & TDS & TH & PH & Na & Cl & So4 \\
\hline Good & 87.5 & 93.75 & 50 & 93.75 & 100 & 87.5 \\
\hline Acceptable & 12.5 & 6.25 & 43.75 & 6.25 & 0.00 & 6.25 \\
\hline Average & 0.00 & 0.00 & 6.25 & 0.00 & 0.00 & 6.25 \\
\hline
\end{tabular}




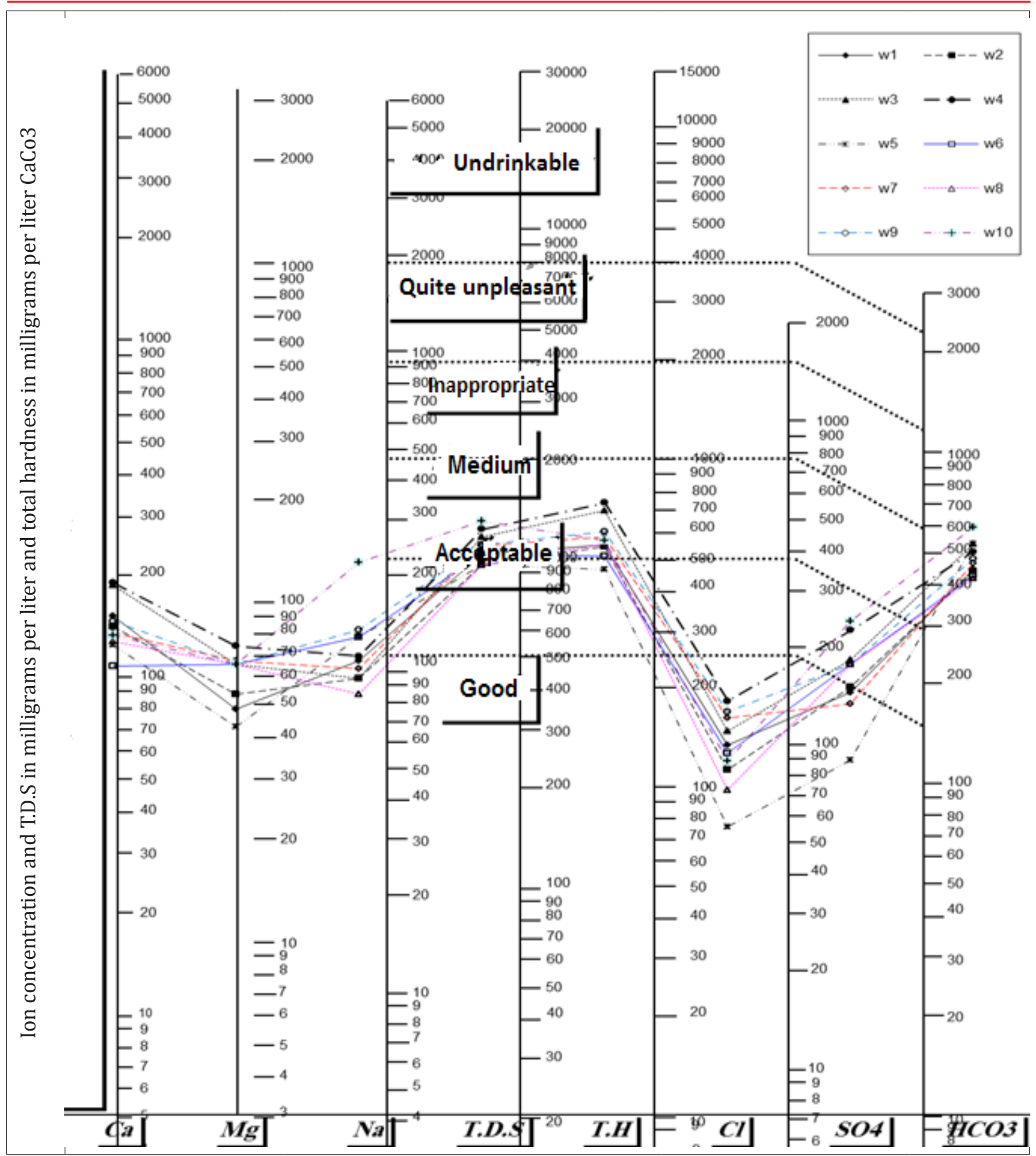

Fig2. Schuler diagram for classification of drinking water quality

As it can be inferred from Table 8, it is observed the qualitative classification of 13 stations in the basin understudying is C2S1 (medium salinity - low sodium) based on the values of SAR and EC form from agricultural view point (irrigation), that is, slightly salty water is suitable for irrigation agricultural lands at their downstream and 2 stations Hossein Abad and Henjin have been salty C3S1 which is definitely suitable for agriculture. Figure 3 shows the Wilcox graph to classify Zayandehrud basin water quality. 
Classification of Zayandehrud River Basin Water Quality Regarding Agriculture, Drinking, and Industrial Usage

Table8. Qualitative classification Zayandehrud basin stations, according to agriculture based on Wilcox graph

\begin{tabular}{|l|l|l|l|l|l|}
\hline Station & Sign & SAR & EC & Water Class & Water quality for agriculture \\
\hline Ghaleh Eslam Abad & A & 0.32 & 385.94 & C2-S1 & Slightly salty - perfect for agriculture \\
\hline Zardfahreh & B & 0.21 & 310.28 & C2-S1 & Slightly salty - perfect for agriculture \\
\hline Tang Zardalu & C & 0.4 & 431.5 & C2-S1 & Slightly salty - perfect for agriculture \\
\hline Charkh o Falak & D & 0.26 & 372.28 & C2-S1 & Slightly salty - perfect for agriculture \\
\hline Band e Ghadimi & E & 0.19 & 346.84 & C2-S1 & Slightly salty - perfect for agriculture \\
\hline Benrud & F & 1.06 & 413.97 & C2-S1 & Slightly salty - perfect for agriculture \\
\hline Hossein Abad & G & 3.67 & 1011.1 & C3-S1 & Passion - usable for agriculture \\
\hline Sarab Hende & H & 1.27 & 517.48 & C2-S1 & Slightly salty - perfect for agriculture \\
\hline Abbas Abad exit & I & 1.14 & 503.68 & C2-S1 & Slightly salty - perfect for agriculture \\
\hline Ghaleh Shahrokh & J & 0.33 & 341.32 & C2-S1 & Slightly salty - perfect for agriculture \\
\hline Eskandari & K & 0.38 & 479.51 & C2-S1 & Slightly salty - perfect for agriculture \\
\hline Regulatory Dams & L & 0.32 & 314.12 & C2-S1 & Slightly salty - perfect for agriculture \\
\hline Zamankhan bridge & M & 0.37 & 321.59 & C2-S1 & Slightly salty - perfect for agriculture \\
\hline Pol e Kale & N & 0.59 & 373.86 & C2-S1 & Slightly salty - perfect for agriculture \\
\hline Henjin & O & 1.69 & 1148.47 & C3-S1 & Passion - usable for agriculture \\
\hline
\end{tabular}

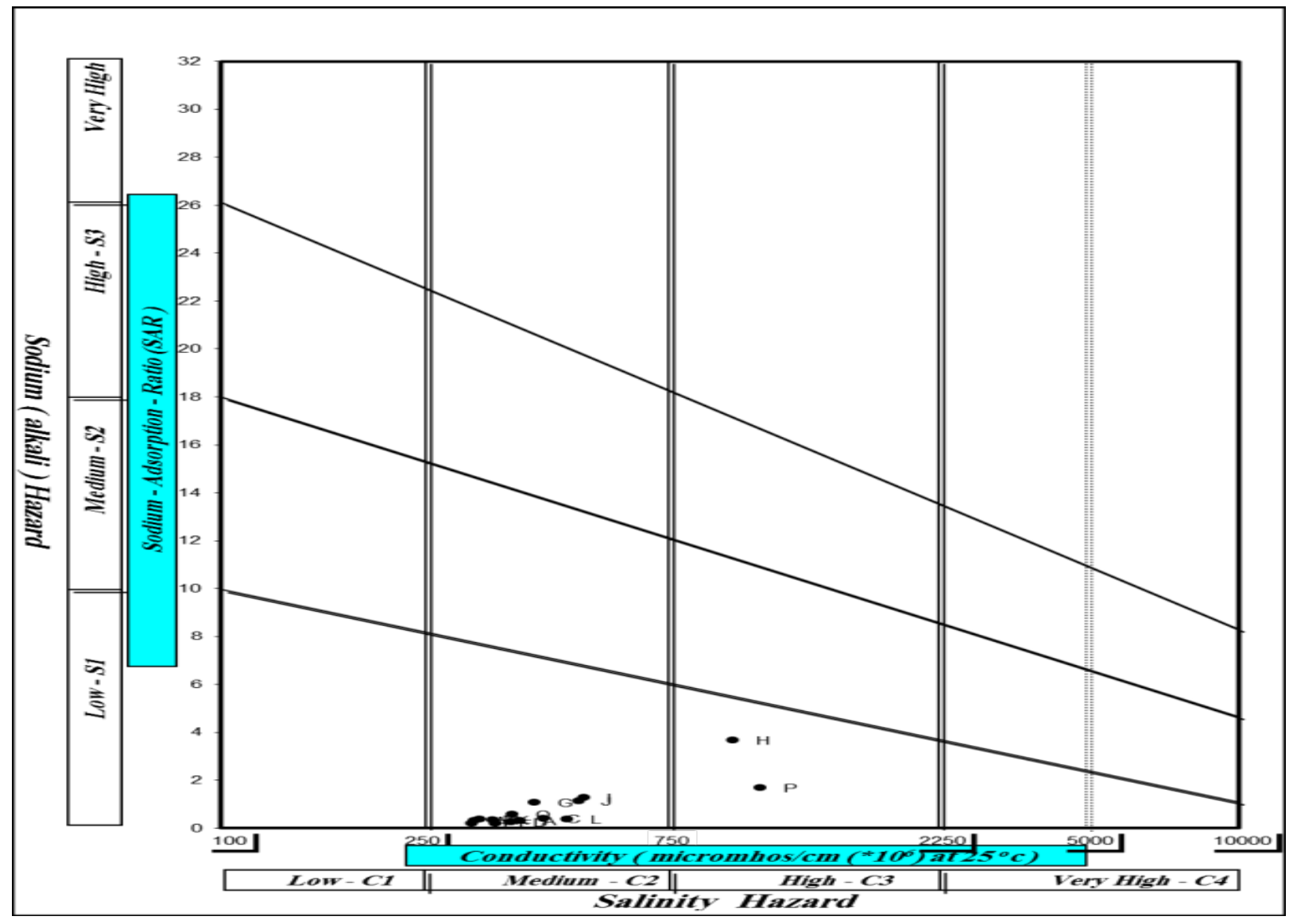

Fig3. Wilcox diagram for classification of water quality for agriculture - irrigation 
Classification of Zayandehrud River Basin Water Quality Regarding Agriculture, Drinking, and Industrial Usage The most important determinant of water quality is its hardness. Water hardness is defined as the number of $\mathrm{mEq} g$ of calcium and magnesium ions in a cubic $\mathrm{dB}$. Hardness is divided into three types: 1) temporary hardness which is related to calcium bicarbonate and magnesium soluble in water. In this case, bicarbonate of calcium and magnesium are converted to insoluble carbonates by heating and boiling water and in the form of solids and exit from the environment. 2) Permanent hardness is produced because of other calcium and magnesium salts such as nitrate, sulfate and chloride which are not deposited by boiling water and remain in the form of solution, and 3 ) total hardness is defined as the sum of permanent and temporary hardships . According to Table 9, water quality of ten stations has been hard water, four stations are fairly hard and the only Henjin station is quite hard.

Table9. Qualitative classification for stations of Zayandehrud river basin based on temporary and permanent hardness

\begin{tabular}{|l|l|l|l|l|}
\hline Station & Total hardness & Permanent hardness & Temporary hardness & Water quality \\
\hline Ghaleh Eslam Abad & 188.67 & 0 & 188.67 & Hard \\
\hline Zardfahreh & 149.69 & 0 & 149.69 & Relatively hard \\
\hline Tang Zardalu & 200.31 & 0 & 200.31 & Hard \\
\hline Charkh o Falak & 173.12 & 0 & 173.12 & Hard \\
\hline Band e Ghadimi & 176.73 & 0 & 176.73 & Hard \\
\hline Benrud & 147.79 & 0 & 147.79 & Relatively hard \\
\hline Hossein Abad & 228.03 & 0 & 228.03 & Hard \\
\hline Sarab Hende & 174.18 & 0 & 174.18 & Hard \\
\hline Abbas Abad exit & 175.32 & 0 & 175.32 & Hard \\
\hline Ghaleh Shahrokh & 158.15 & 0 & 158.15 & Hard \\
\hline Eskandari & 226.04 & 0 & 226.04 & Hard \\
\hline Regulatory Dams & 149.08 & 0 & 149.08 & Relatively hard \\
\hline Zamankhan bridge & 149.2 & 0 & 149.2 & Relatively hard \\
\hline Pol e Kale & 161.94 & 0 & 161.94 & Hard \\
\hline Henjin & 426.86 & 65.05 & 361.81 & Very hard \\
\hline
\end{tabular}

Table 10 shows types and kinds of water quality for 15 stations under study. According to this table, type and kind of water quality in 13 stations have been calcic bicarbonate and just two stations; Hossein Abad and Henjin have had sodic sulphate type and kind.

Table10. Ionic frequency, type and kind of water and how to develop it

\begin{tabular}{|l|l|l|l|l|l|}
\hline Station & $\begin{array}{l}\text { Type of } \\
\text { water }\end{array}$ & Water facies & Type and facies & $\begin{array}{l}\text { C a t i o n s } \\
\text { concentration }\end{array}$ & $\begin{array}{l}\text { Concentration of } \\
\text { anions }\end{array}$ \\
\hline Ghaleh Eslam Abad & Bicarbonate & Calcic & Bicarbonate calcic & $\mathrm{Ca}>\mathrm{Mg}>\mathrm{Na}+\mathrm{K}$ & $\mathrm{HCO}>\mathrm{SO} 4>\mathrm{Cl}$ \\
\hline Zardfahreh & Bicarbonate & Calcic & Bicarbonate calcic & $\mathrm{Ca}>\mathrm{Mg}>\mathrm{Na}+\mathrm{K}$ & $\mathrm{HCO}>\mathrm{SO} 4>\mathrm{Cl}$ \\
\hline Tang Zardalu & Bicarbonate & Calcic & Bicarbonate calcic & $\mathrm{Ca}>\mathrm{Mg}>\mathrm{Na}+\mathrm{K}$ & $\mathrm{HCO}>\mathrm{Cl}>\mathrm{SO} 4$ \\
\hline Charkh o Falak & Bicarbonate & Calcic & Bicarbonate calcic & $\mathrm{Ca}>\mathrm{Mg}>\mathrm{Na}+\mathrm{K}$ & $\mathrm{HCO}>\mathrm{SO} 4>\mathrm{Cl}$ \\
\hline Band e Ghadimi & Bicarbonate & Calcic & Bicarbonate calcic & $\mathrm{Ca}>\mathrm{Mg}>\mathrm{Na}+\mathrm{K}$ & $\mathrm{HCO}>\mathrm{SO} 4>\mathrm{Cl}$ \\
\hline Pole Bardekan & Bicarbonate & Calcic & Bicarbonate calcic & $\mathrm{Ca}>\mathrm{Mg}>\mathrm{Na}+\mathrm{K}$ & $\mathrm{HCO}>\mathrm{SO} 4>\mathrm{Cl}$ \\
\hline Benrud & Bicarbonate & Calcic & Bicarbonate calcic & $\mathrm{Ca}>\mathrm{Na}+\mathrm{K}>\mathrm{Mg}$ & $\mathrm{HCO}>\mathrm{SO} 4>\mathrm{Cl}$ \\
\hline Hossein Abad & Sulfated & Sodic & Sodic sulphate & $\mathrm{Na}+\mathrm{K}>\mathrm{Ca}>\mathrm{Mg}$ & $\mathrm{SO}>\mathrm{HCO}>\mathrm{Cl}$ \\
\hline Sarab Hende & Bicarbonate & Calcic & Bicarbonate calcic & $\mathrm{Ca}>\mathrm{Na}+\mathrm{K}>\mathrm{Mg}$ & $\mathrm{HCO}>\mathrm{Cl}>\mathrm{SO} 4$ \\
\hline
\end{tabular}


Classification of Zayandehrud River Basin Water Quality Regarding Agriculture, Drinking, and Industrial Usage

\begin{tabular}{|l|l|l|l|l|l|}
\hline Abbas Abad exit & Bicarbonate & Calcic & Bicarbonate calcic & $\mathrm{Ca}>\mathrm{Na}+\mathrm{K}>\mathrm{Mg}$ & $\mathrm{HCO}>\mathrm{Cl}>\mathrm{SO} 4$ \\
\hline Ghaleh Shahrokh & Bicarbonate & Calcic & Bicarbonate calcic & $\mathrm{Ca}>\mathrm{Mg}>\mathrm{Na}+\mathrm{K}$ & $\mathrm{HCO}>\mathrm{Cl}>\mathrm{SO} 4$ \\
\hline Eskandari & Bicarbonate & Calcic & Bicarbonate calcic & $\mathrm{Ca}>\mathrm{Mg}>\mathrm{Na}+\mathrm{K}$ & $\mathrm{HCO}>\mathrm{SO} 4>\mathrm{Cl}$ \\
\hline Regulatory Dams & Bicarbonate & Calcic & Bicarbonate calcic & $\mathrm{Ca}>\mathrm{Mg}>\mathrm{Na}+\mathrm{K}$ & $\mathrm{HCO}>\mathrm{SO} 4>\mathrm{Cl}$ \\
\hline Zamankhan bridge & Bicarbonate & Calcic & Bicarbonate calcic & $\mathrm{Ca}>\mathrm{Mg}>\mathrm{Na}+\mathrm{K}$ & $\mathrm{HCO}>\mathrm{SO} 4>\mathrm{Cl}$ \\
\hline Pol e Kale & Bicarbonate & Calcic & Bicarbonate calcic & $\mathrm{Ca}>\mathrm{Mg}>\mathrm{Na}+\mathrm{K}$ & $\mathrm{HCO}>\mathrm{SO} 4>\mathrm{Cl}$ \\
\hline Henjin & Sulfated & Magnesium & Magnesium Sulfated & $\mathrm{Mg}>\mathrm{Na}+\mathrm{K}>\mathrm{Ca}$ & $\mathrm{SO} 4>\mathrm{HCO}>\mathrm{Cl}$ \\
\hline
\end{tabular}

Another factor that affects the water quality is corrosive. Lack of control of chemical water quality in the distribution network caused corrosion phenomena and deposition and resulted in health and economic harm. Corrosive is one of the most important problems in the water industry and can cause general health, changing quality and high cost of the water distribution system and it makes economic, aesthetic and health problems. Corrosive water will also create problems for beneficiaries. Table 11 represents a qualitative classification of stations in the Zayandehrud basin based on a Langelier index that its interpretation will be shown in Table 5. According to the table, qualitative classification of stations under study has been corrosive from industrial viewpoint and based on aLangelier index except Hossein Abad station which has been deposited.

Table11. Qualitative classification of stations in the Zayandehrud basin based on a Langelierindex (Industrial)

\begin{tabular}{|l|l|l|l|l|}
\hline Station & PH & PHs & PHs-PH & Water quality \\
\hline Ghaleh Eslam Abad & 7.43 & 8.5 & -1.066 & Corrosive \\
\hline Zardfahreh & 7.44 & 8.8 & -1.364 & Corrosive \\
\hline Tang Zardalu & 7.54 & 8.4 & -0.865 & Corrosive \\
\hline Charkh o Falak & 7.36 & 8.5 & -1.142 & Corrosive \\
\hline Band e Ghadimi & 7.47 & 8.8 & -1.329 & Corrosive \\
\hline Pole Bardekan & 7.08 & 8.8 & -1.722 & Corrosive \\
\hline Benrud & 7.74 & 8.2 & -0.46 & Corrosive \\
\hline Hossein Abad & 7.83 & 7.5 & 0.33 & Sedimentation \\
\hline Sarab Hende & 7.54 & 8 & -0.462 & Corrosive \\
\hline Abbas Abad exit & 7.45 & 8 & -0.552 & Corrosive \\
\hline Ghaleh Shahrokh & 7.59 & 8.6 & -1.012 & Corrosive \\
\hline Eskandari & 7.58 & 8.4 & -0.822 & Corrosive \\
\hline Regulatory Dams & 7.63 & 8.6 & -0.975 & Corrosive \\
\hline Zamankhan bridge & 7.63 & 8.6 & -0.974 & Corrosive \\
\hline Pol e Kale & 7.46 & 8.3 & -0.836 & Corrosive \\
\hline Henjin & 7.37 & 7.5 & -0.129 & Corrosive \\
\hline
\end{tabular}

Corrosive waters make significant costs through different ways which the most important ones are as follows: damage to plumbing and residential water supply network, creating a bitter taste to water due to the relatively large amounts metallic compounds, increasing of loss and risk of poisoning because of the use of water which have toxic metals such as lead and copper. 


\section{CONCLUSION}

Iran is located in arid and semi-arid of the world and it has shortage of freshwater resources. The current surface water or rivers are the most important water resources which have a major role in supplying water required for various activities such as agriculture, industry, drinking water. Zayandehrud is the largest river in the central plateau of Iran, which originated from central Zagros Mountains, especially ZardKuh Bakhtiari and extends in Iran's central desert some $200 \mathrm{~km}$ to the East and eventually goes Gavkhuni Marsh. So, to review the status of water use and protection of water resources against pollution, especially in the global water crisis is necessary and vital. Given the importance of Water quality monitoring, assessment water quality parameter of the 15 stations in the river basin Zayandehrud has been done during 5 decades from 1967-2009 for drinking, agriculture and industry which are goal of the present research. Surveying the results shows that of Drinking Water Quality based on the diagram Schuler is good and acceptable. Regarding agriculture and irrigation, according to Wilcox diagram, except for two stations Hossein Abad and Henjin which were (salty C3S1), the other stations suitable were a bit salty but suitable for agriculture (C2S1). Water quality of ten stations has been hard water; four stations fairly hard and the only Henjin station has been estimated quite hard. The type and kind of this basin water has been calcic bicarbonate at 13 stations and in two stations Hossein Abad and Henjin have been sodic sulfate and Magnesium Sulfated. Qualitative classification of stations based on both industrial and according to Langelier index is estimated to be corrosive except Hossein Abad station that has been deposited. It is suggested other estimates shall be carried out in accordance with current standards for the basin such as heavy metal pollution, toxic metals, pesticides, turbidity, organic substances, domestic sewage, pollution, etc.,

\section{REFERENCES}

1. Azrina, M., Yap, C., Rahim Ismail, A., Ismail, A., \& Tan, S. (2006). Anthropogenic impacts on the distribution and biodiversity of benthic macroinvertebrates and water quality of the Langat River, Peninsular Malaysia. Ecotoxicology and Environmental Safety, 64(3), 337-347.

2. Chapman, D. V., Organization, W. H., \& Press, C. (1996). Water quality assessments: a guide to the use of biota, sediments and water in environmental monitoring: E \& Fn Spon London.

3. Esmaili sari, A. (2003). Pollution, Health and Environmental Standards: Naghshe Mehr.

4. Ghasemi, A., Zare, A. H., Shahsavar, A., \& Yaghobi Kikileh, B. (2010). THE STUDY OF VARIATION OF QUALITY AND QUANTITY OF GROUND WATER IN HAMEDAN-BAHAR AREA. PLANT AND ECOSYSTEM.

5. Jabari, E., \& Najmi, N. (2010). Instruction for surface water quality monitoring (Vol. Code : 522). Islamic Republic of Iran Vice presidency for strategic planning and supervision, Ministry of Energy publishing.

6. Misaghi, F., \& Mohammadi, K. (2004). Predicting the changes in Zayandehrud river water quality by using artificial neural networks. Paper presented at the Second National Student Conference, Soil and Water Resources, Shiraz University

7. Mossadegh, A. (2003). Global Destruction of environment and future of the world. Tehran: Agricultural Sciences Publishing.

8. Mostakmeli, A., \& Tarshiziyan, H. (2000). The study of hydrochemical of rivers in Shirin Darreh basin. J. Earth Sci. Geological Survey of Iran.

9. Najafi, P., Tabatabai, S., H. , \& Savage, R. (2006). Comparing the quality Zayandehrud River between PolKaleh and Lenj stations. Paper presented at the First Regional Conference on Optimum Utilization of Water Resources in Karun and Zayandehrud basin, Shahrekord. 
Classification of Zayandehrud River Basin Water Quality Regarding Agriculture, Drinking, and Industrial Usage

10. Pesce, S. F., \& Wunderlin, D. A. (2000). Use of water quality indices to verify the impact of Córdoba City (Argentina) on Suquía River. Water research, 34(11), 2915-2926.

11. Sundaray, S. K., Nayak, B. B., \& Bhatta, D. (2009). Environmental studies on river water quality with reference to suitability for agricultural purposes: Mahanadi river estuarine system, India-a case study. Environmental monitoring and assessment, 155(1-4), 227-243.

12. Vega, M., Pardo, R., Barrado, E., \& Debán, L. (1998). Assessment of seasonal and polluting effects on the quality of river water by exploratory data analysis. Water research, 32(12), 3581-3592.

Citation: Mohammad Salarian, Masumeh Najafi, S Vahid Hosseini, Mohammad Heydari, "Classification of Zayandehrud River Basin Water Quality Regarding Agriculture, Drinking, and Industrial Usage", American Research Journal of Civil and Structural Engineering, vol 1, no. 1, pp. 47-57.

Copyright (C) Mohammad Salarian, Masumeh Najafi, S Vahid Hosseini, Mohammad Heydari, This is an open access article distributed under the Creative Commons Attribution License, which permits unrestricted use, distribution, and reproduction in any medium, provided the original work is properly cited. 